\title{
EVALUASI PROGRAM SKB (SANGGAR KEGIATAN BELAJAR) KABUPATEN KAMPAR DALAM MENANGGULANGI PENDIDIKAN ANAK PUTUS SEKOLAH
}

\author{
Jusmareni $^{1)}$ \\ Zulfan Saam ${ }^{2)}$ \\ Almasdi Syahza ${ }^{3)}$ \\ ${ }^{1)}$ Post Graduate Student of Riau University \\ ${ }^{2}$ Lecturer of Education Management Study Programme PPs University of Riau \\ ${ }^{3)}$ Lecturer of Education Management Study Programme PPs University of Riau
}

\begin{abstract}
This study aims to uncover, analyze and evaluate the program SKB ( SKB ) in tackling the education of children dropping out of school in the district of Kampar. This study used a qualitative approach. Data collection is done by observation, interview and documentation. Examination of data validity was tested the validity of the form of triangulation and member checking. Evaluation model used is the model CIPP. From the results of this study indicate that the Program Implementation for SKB Kampar in tackling the education of school children from the evaluation components of context, input, process and products are in both categories because of the four components in the evaluation of only one component of which is the unfavorable category namely the process component. Implementation of the program SKB Kampar district is very helpful in minimizing the number of dropouts in Kampar regency. Evaluation program for SKB in this penelititan Packet focuses on program C. Residents learned in Package $C$ is the citizens who already have a junior high school diploma and diploma Package B. All officials are already earning has taught appropriate educational background, mastery of officials in the presentation of the material based on competence, In the curriculum that need improvement education calendar. Means of support for the implementation of the existing program despite inadequate. Financing for SKB comes from Kampar District Government and some of the learners. In the process of the most important components that must be considered are the obstacles encountered in the implementation of the program should be addressed as soon as possible.
\end{abstract}

Key words : Evaluation Program, SKB, School Children.

ABSTRAK: Penelitian ini bertujuan untuk mengungkap, menganalisa dan mengevaluasi program SKB (Sanggar Kegiatan Belajar) dalam menanggulangi pendidikan anak putus sekolah di Kabupaten Kampar. Penelitian ini menggunakan pendekatan kualitatif. Pengumpulan data dilakukan secara observasi, wawancara dan dokumentasi. Pemerikasaan keabsahan data diuji validitas berupa triangulasi dan member checking. Model evaluasi yang dipakai adalah model CIPP. Dari hasil penelitian ini menunjukkan bahwa Pelaksanaan Program Sanggar Kegiatan Belajar Kabupaten Kampar dalam menganggulangi pendidikan anak putus sekolah mulai dari evaluasi komponen konteks, input, proses dan produk berada pada kategori baik karena dari empat komponen yang di evaluasi hanya satu komponen yang berada pada kategori kurang baik yaitu pada komponen proses. Pelaksanaan program Sanggar Kegiatan Belajar Kabupaten Kampar ini sangat membantu dalam meminimalisasi angka putus sekolah di Kabupaten Kampar. Evaluasi program Sanggar Kegiatan Belajar dalam penelititan ini memfokuskan pada program Kejar Paket C. Warga belajar pada Paket C adalah warga yang sudah memiliki ijazah SMP dan ijazah Paket B. Semua pamong sudah produktif telah mengajar sesuai latar belakang 
pendidikannya, penguasaan pamong dalam penyajian materi berdasarkan kompetensi. Pada kurikulum yang perlu perbaikan kalender pendidikan. Sarana pendukung untuk pelaksanaan program sudah ada meskipun belum memadai. Pembiayaan Sanggar Kegiatan Belajar berasal dari Pemerintah Daerah Kabupaten Kampar dan ada juga dari warga belajar. Pada komponen proses yang paling utama yang harus diperhatikan adalah hambatan yang ditemui dalam pelaksanaan program harus ditanggulangi secepatnya.

Kata kunci : Evaluasi Program, Sanggar Kegiatan Belajar, Anak Putus Sekolah.

\section{LATAR BELAKANG}

Pembukaan UUD 1945 menegaskan bahwa salah satu tugas negara adalah mencerdaskan kehidupan bangsa, dan untuk itu pula maka setiap warga negara memiliki hak untuk mendapatkan pelayanan pendidikan yang layak sesuai dengan perkembangan zaman dan kemajuan ilmu pengetahuan. Pendidikan di Indonesia kini memasuki era reformasi dengan pembaharuan yang radikal yang didukung oleh semangat otonomi daerah dalam Undang-undang nomor 22 tahun 1999 serta Undang-undang nomor 25 tahun 1999.

Program-program PNF yang ada di SKB (Sanggar Kegiatan Belajar) adalah program PAUD, pendidikan kesetaraan paket A, B, dan C, serta berbagai program kecakapan hidup untuk membekali peserta didik dengan keterampilan yang "layak jual” (marketable). Disamping itu, SKB (Sanggar Kegiatan Belajar) bisa melakukan penyuluhan untuk menyadarkan bahaya merokok hingga bahaya narkoba, HIV/ AIDS, Flu burung, Trafficking, bahaya Seks bebas dan tentang penyadaran akan bahaya resiko bencana dan masalah kemasyarakatan yang semakin komplek pun bisa menjadi bahan pembelajaran yang dikemas sedemikian rupa sehingga mudah dipahami oleh paserta didik yang tergabung dalam kelompok belajar. Semuanya ini diprogramkan dalam rangka untuk pembelajaran kaum tertinggal sehingga terbebas dari ketidak tahuan, dan untuk pembelajaran kaum tersingkir sehingga terbebas dari keterpinggiran dan ketidakberdayaan (Dit dikmas, 2009).

Pelaksanaan program SKB (sanggar Kegiatan Belajar) tersebut diharapkan bermanfaat bagi Pemerintah Kabupaten Kampar dalam menanggulangi pendidikan anak putus sekolah. Tetapi fenomena yang terjadi di lapangan berbeda dengan yang diharapkan. Adapun permasalahan tersebut antara lain:

Pertama, Permasalahan yang berkaitan dengan warga belajar adalah lokasi tempat tinggal warga belajar saling berjauhan sehingga sulit mendapatkan satu kelompok sebanyak 40 orang warga belajar, Latar belakang sosial ekonomi warga belajar lemah sehingga frekuensi kehadirannya sangat rendah, Warga belajar menjadi pencari nafkah keluarga, mereka hanya belajar kalau waktu mengizinkan, motivasi belajar rendah, mereka berpendapat tanpa belajarpun mereka sudah mendapatkan uang, sehingga masih banyak angka putus sekolah di Kabupaten Kampar ini.

Kedua, permasalahan yang berkaitan dengan pamong belajar adalah sulit mendapatkan tutor yang memiliki latar belakang keguruan, khususnya tutor IPA dan Bahasa Inggris, usaha peningkatan kemampuan pamong belajar tidak merata, masih ada pamong belajar yang tidak pernah ditatar atau mendapatkan pelatihan dan tempat tinggal pamong belajar jauh dari SKB (Sanggar Kegiatan Belajar) sehingga pamong sering tidak datang dalam proses belajar.

Ketiga, permasalahan yang berkaitan dengan sarana dan prasarana adalah lokasi gedung SKB (Sanggar Kegiatan Belajar) jauh dari tempat tinggal warga belajar, dan fasailitas belajar kurang memadai, jumlah modul terbatas, yaitu 1 modul untuk 3 orang warga belajar, yang seharusnya 1 modul untuk tiap warga belajar, akibatnya mereka sukar untuk dapat melaksanakan proses belajar mandiri, 
terbatasnya jumlah buku yang dapat menambah wawasan warga belajar, kurang dimanfaatkannya sarana belajar lokal atau yang tersedia di lokasi kegiatan.

Berdasarkan fenomena di atas, pelaksanaan program wajib belajar 9 tahun di Kabupaten Kampar perlu dikaji secara ilmiah melalui penelitian yang berjudul Evaluasi Program SKB (Sanggar Kegiatan Belajar) Kabupaten Kampar dalam Menanggulangi Pendidikan Anak Putus Sekolah.

\section{METODE PENELITIAN}

Sesuai dengan rumusan masalah, maka tujuan penelitian untukmengungkap, menganalisa secara jelas dan cermat terhadap beberapa hal, yaitu:

1. Mendiskripsikan konteks (context) yang ada dalam program SKB (Sanggar Kegiatan Belajar) Kabupaten Kampar Dalam Menanggulangi Pendidikan Anak Putus Sekolah.

2. Mendiskripsikan masukan (input) dilihat dari sarana prasarana pendukung, sumber dana pelaksanaan program SKB (Sanggar Kegiatan Belajar) Kabupaten Kampar dalam menanggulangi pendidikan anak putus sekolah.

3. Mendidkripsikan proses (process) pelaksanaan program SKB (Sanggar Kegiatan Belajar) Kabupaten Kampar dilihat dari persiapan, pelaksanaan , monitoring dan hambatan yang ditemukan dalam pelaksanaan program SKB (Sanggar Kegiatan Kabupaten Kampar)

4. Mendiskrpsikan hasil (product) yang dicapai dilihat dari hasil ujian uji kompetensi dan dampak kelulusan dari program SKB (Sanggar Kegiatan Belajar) Kabupaen Kampar khususnya pada program kejar paket C.

Penelitian ini dilakukan di UPTD SKB (Sanggar Kegiatan Belajar) Kabupaten Kampar dan waktu penelitiannya dimulai dari awal bulan Juli sampai dengan akhir bulan September 2014.

1. Jenis data

Penelitian dilaksanakan menggunakan data primer, yaitu data yang diperoleh seorang peneliti dari sumber utama secara langsung. Data ini hanya digunakan bagi peneliti saja (data yang tidak dipublikasikan), dan tidak dapat digunakan oleh peneliti yang lain karena tujuan penelitiannya berbeda.

\section{Sumber data}

Dalam penelitian ini data dan sumber data yang diambil adalah melalui Kepala UPTD SKB Kabupaten Kampar, Pamong Belajar dan Warga Belajar selaku pelaksana Program SKB (Sanggar Kegiatan Belajar) di Kabupaten Kampar.

Terdapat beberapa teknik pengumpulan data, tetapi dalam penelitian ini yang digunakan adalah teknik wawancara, observasi dan dokumentasi. Data diperoleh dari: Kepala SKB (Sanggar Kegiatan Belajar), Pamong dan Tutor, Warga Belajar Paket C dan Alumni dari SKB (Sanggar Kegiatan Belajar) Kabupaten Kampar.

Prosedur dalam memperoleh data melalui langkah-langkah sebagai berikut:

a. Menjumpai informan utama, yaitu Kepala SKB dan tenaga pendidik (pamong belajar) dan kependidikan yang menjalankan program SKB

b. Mempersiapkan wawancara berupa pertanyaan-pertanyaan yang telah disusun secara terstruktur

c. Mempersiapkan dokumentasi dan hasil pengamatan penelitian

Selanjutnya berdasarkan jenis penelitian ini yaitu penelitian kualitatif, maka analisis data dilakukan saat pelaksanaan penelitian, baik langsung dilakukan pada saat pengambilan data maupun setelah data terkumpul memakai teknik yang dikemukakan oleh Jhon W Creswell dalam Diah.

\section{HASIL PEMBAHASAN}

\section{Latar Penelitian}

- Sejarah Berdirinya SKB (Sanggar Kegiatan Belajar) Kabupaten Kampar

Di awal berdirinya lembaga ini bernama Pusat Latihan Pendidikan Masyarakat (PLPM) yang berkedudukan di Pasar Rumbio Kecamatan 
Kampar Kabupaten Kampar yang merupakan Unit Pelaksana Teknis Bidang Pendidikan Masyarakat Kanwil Depdikbud Propinsi Riau.

Pada tanggal 23 Juni 1978 berdasarkan Surat Keputusan Menteri Pendidikan dan Kebudayaan Republik Indonesia Nomor: 0208/ O/1978 tentang Tupoksi, Struktur Organisasinya dan Perubahan nama menjadi Sanggar Kegiatan Belajar (SKB) Bangkinang Kabupaten Kampar Propinsi Riau yang merupakan Ujung tombak Pelaksanaan Program Pendidikan Luar Sekolah Pemuda dan Olahraga yang bisa menghasilkan Program Percontohan bagi Pendidikan Luar Sekolah Pemuda dan Olahraga untuk itu SKB (Sanggar Kegiatan Belajar) dituntut untuk terus menerus meningkatkan Profesionalisme dengan potensi yang ada sehingga menjadi modal yang mampu untuk berkiprah di Dunia Pendidikan khususnya Pendidikan Luar Sekolah Pemuda dan Olahraga.

Berdasarkan Surat Keputusan Menteri Pendidikan dan Kebudayaan Republik Indonesia Nomor: 0208/O/1978 SKB berkedudukan di Ibu Kota Kabupaten untuk itu Kantor SKB Bangkinang Kabupaten Kampar pindah ke Jalan Dt. Tabano No. 02 Bangkinang.

Pada tahun 1985 Kantor SKB (Sanggar Kegiatan Belajar) Bangkinang pindah ke gedung baru yng beralamat Jalan Dt. Harunsyah KM. 2,3 Salo Bangkinang sampai sekarang.

\section{Temuan Penelitian}

- Deskripsi Konteks

Sanggar Kegiatan Belajar ( SKB) merupakan Unit Pelaksana Teknis Dinas Pendidikan dan Kebudayaan yang menangani Pendidikan Luar Sekolah yang memiliki tugas pokok serta fungsinya sebagai pembuat percontohan dan pengendali mutu Program Pendidikan Luar Sekolah dan Pemuda. Pendidikan luar sekolah melaksanakan program pembelajaran yang berorientasi pada kebutuhan masyarakat dan kebutuhan dunia kerja (pasar). Dalam melaksanakan kegiatannya, SKB (Sanggar Kegiatan Belajar) mempunyai dasar hukum secara yuridis dan dasar operasional yang melandasi pelaksanaan tugas pokok dan fungsinya. Hal ini mengingat bahwa sasaran Pendidikan Luar Sekolah adalah mereka yang memerlukan kebiasaan yang cepat dan menghasilkan. Sehingga dapat dikatakan bahwa SKB (Sanggar Kegiatan Belajar) merupakan lembaga pendidikan alternatif bagi masyarakat yang tidak berkesempatan mengikuti pendidikan dilembaga pendidikan formal. Warga belajar adalah warga masyarakat yang mengikuti pembelajaran di SKB (Sanggar Kegiatan Belajar).

Data yang diperoleh melalui monitoring dan evaluasi program SKB (Sanggar Kegiatan Belajar) Kabupaten Kampar menunjukkan bahwa program SKB (Sanggar Kegiatan Belajar) Kabupaten Kampar sudah memenuhi standar, sebagian besar program SKB Kabupaten Kampar sudah dapat dijalankan dengan baik terutama program Kejar Paket C. Walaupun masih ada yang perlu diperbaiki yaitu sarana dan prasarana masih kurang memadai terutama dalam proses belajar mengajar dengan warga belajar. Selain itu masih ada program yang ada di SKB (Sanggar Kegiatan Belajar) Kabupaten Kampar yang belum berjalan sesuai dengan rencana.

Adapun dasar hukum dari Program SKB (Sanggar Kegiatan Belajar) yang digunakan sebagai rujukan di antaranya:

1. Undang-Undang RI Nomor 20 Tahun 2003 tentang Sistem Pendidikan Nasional.

2. Surat Keputusan Menteri Pendidikan dan Kebudayaan Republik Indonesia Nomor: 0208/O/1978 tentang Tupoksi, Struktur Organisasinya.

3. UU No. 22 Tahun 2000, tentang Otonomi Daerah.

4. Peraturan Daerah No. 07 Tahun 2001 tanggal 13 Agustus 2001, tentang Susunan Organisasi dan Tata Kerja Dinas Pendidikan Pemuda dan Olahraga.

5. Keputusan Bupati Kampar Nomor 229 Tahun 2001 tanggal 15 Oktober 2001, tentang Struktur Organisasi dan Unit Pelaksana Teknis Dinas (UPTD) Sanggar 
Kegiatan Belajar (SKB) Bangkinang Kabupaten Kamparyang merupakan UPTD di lingkup Dinas Pemuda dan Olahraga Kabupaten Kampar.

6. Keputusan Bupati Kampar Nomor 127 Tahun 2003 tanggal 18 Juli 2003, tentang Uraian Tugas Jabatan Struktural Unit Pelaksana Teknis Dinas (UPTD) pada Dinas Pendidikan Pemuda dan Olahraga Kabupaten Kampar.

\section{- Deskripsi Input}

Dari hasil wawancara dan observasi menunjukkan bahwa terdapat 5 aspek dan 13 sub aspek, yang telah memenuhi standar objektifitas yakni 1 aspek dan 9 sub aspek, 1 aspek dan 1 sub aspek yang tidak memenuhi standar objektifitas yaitu tutor, 2 aspek dan 2 sub aspek yang perlu perbaikan yaitu kurikulum dan sarana pendukung pendidikan, kemudian 1 aspek dan 1 sub aspek yang bisa ditolerir yaitu pembiayaan.

\section{- Deskripsi Proses}

Proses (process) pelaksanaan program Sanggar Kegiatan Belajar (SKB) dilihat dari sosialisasi pelaksanaan, pelaksanaan, monitoring, dan hambatan pelaksanaan program SKB Kabupaten Kampar.

Dari hasil wawancara dan observasi menunjukkan bahwa terdapat 9 aspek dan 28 sub aspek. Dari 28 subaspek terdapat 3 sub aspek yang tidak memenuhi standar objektif yaitu penggunan media pembelajaran, pemberian materi remedial dan ketepatan waktu pamong belajar datang ketempat belajar. Kemudian pada aspek hambatan yang ditemui dalam pelaksanaan program ke 3 sub aspek memang ditemukan hambatannya

\section{- Deskripsi Produk}

Dari hasil wawancara, dokumentasi dan observasi menunjukkan bahwa aspek telah memenuhi standar objektif. Pada komponen produk ini ada 3 aspek yaitu: aspek hasil pelaksanaan program, aspek tingkat keberhasilan dari warga belajar dan aspek dampak lulusan.

\section{Pembahasan}

- Evaluasi Konteks

Proses validasi data dilakukan dengan member checking dan triangulasi data. Peneliti melakukan member checking dengan membawa kembali hasil penemuan penelitian kepada narasumber untuk memastikan bahwa peneliti tidak melakukan kesalahan dalam mengintepretasikan hasil wawancara. Triangulasi dilakukan dengan membandingkan informasi dari partisipan dengan hasil observasi dan dokumentasi.

Berdasarkan uraian di atas bahwa konteks program SKB (Sanggar Kegiatan Belajar) adalah suatu program yang berada di bawah naungan Dinas Pendidikan Kabupaten Kampar yang meliputi latar balakang, tujuan atau hasil yang diharapkan, sumber daya manusia dan sarana lembaga tersebut. SKB (Sanggar Kegiatan Belajar) Kabupaten Kampar dalam melaksanakan programnya terutama untuk menanggulangi pendidikan anak putus sekolah diawali dengan penyusunan rencana kegiatan. Adapun tujuan dari penyusunan rencana kegiatan ini adalah sebagai panduan dalam penyelenggaraan kegiatan program, sebagai acuan analisis, sebagai pedoman dan pembelajaran standar penyelenggaraan kegiatan untuk mencapai tujuan yang telah direncanakan sebelumnya. Rencana operasional kegiatan program SKB (Sanggar Kegiatan Belajar) meliputi latar belakang, tujuan, sasaran, sumber dana dan tempat pelaksanaan kegiatan.

Hal seperti ini telah diungkapkan oleh kepala SKB sebagai berikut:

“......Tujuan berdirinya SKB (Sanggar Kegiatan Belajar) sudah tertulis di buku profil UPTD SKB Kabupaten Kampar yaitu merupakan unit pelaksana teknis pendidikan Luar Sekolah yang mempunyai peranan penting bagi keberhasilan program-program PLS serta sangat berperan penting dalam mengurangi angka anak putus sekolah di lingkungan Kabupaten Kampar terutama dalam program belajar paket B setara dengan SMP dan kejar Paket $C$ setara dengan SMA." (Transkip wawancara dengan Kepala SKB) 
Berdasarkan temuan ternyata tujuan program dari SKB (Sanggar Kegiatan Belajar) Kabupaten Kampar dalam menanggulangi pendidikan anak putus sekolah berada pada katagori sangat baik karena aspek dan sub aspek memenuhi standar objektif. Artinya tujuan program yang ada di SKB (Sanggar Kegiatan Belajar) Kabupaten Kampar dapat menghasilkan keluaran atau produk yang dapat bersaing dalam dunia pendidikan dan ilmu pengetahuan serta di dunia kerja dan merupakan tenaga kerja yang memiliki keahlian profesional, yaitu tenaga kerja yang memiliki tingkat pengetahuan, keterampilan dan etos kerja yang sesuai dengan tuntutan lapangan kerja.

Hal di atas sejalan dengan Undang-Undang Sistem Pendidikan Nasional No. 20 tahun 2003 yang menyatakan: "Pendidikan bertujuan untuk berkembangnya potensi peserta didik agar menjadi manusia yang beriman dan bertakwa kepada Tuhan Yang Maha Esa, berakhlak mulia, sehat, berilmu, cakap, kreatif, mandiri, dan menjadi warga negara yang demokratis serta bertanggung jawab”.

Hasil analisis peneliti dari hasil wawancara dari informan dan data yang diperoleh bahwa evaluasi pada komponen konteks peneliti dapat menyimpulkan bahwa tujuan dari program SKB (Sanggar Kegiatan Belajar) Kabupaten Kampar sudah sangat baik dalam menanggulangi pendidikan anak putus sekolah. Untuk itu pada komponen konteks ini SKB (Sanggar Kegiatan Belajar) Kabupaten Kampar agar dapat mempertahankan programnya supaya dapat menggali sumber daya manusia yang berkompeten pada umumnya dan dapat menanggulangi pendidikan anak putus sekolah pada khususnya.

\section{- Evaluasi Input}

Masukan (input) dilihat dari warga belajar, persyaratan administrasi, tutor dan pamong belajar, kurikulum, sarana prasarana pendukung, pembiayaan (sumber dana) pada program SKB (Sanggar Kegiatan Belajar) Kabupaten Kampar.
Warga belajar pada SKB (Sanggar Kegiatan Belajar) Kabupaten Kampar harus terdaftar secara administrasi di SKB (Sanggar Kegiatan Belajar) tersebut. Data warga belajar tersebut dapat dilihat pada pegawai Tata Usaha di SKB (Sanggar Kegiatan Belajar) Kabupaten Kampar.

“.............kepala bagian PLS Dinas

Pendidikan dan Kebudayaan Kabupaten Kampar memberikan persyaratan kepada SKB (Sanggar Kegiatan Belajar) Kabupaten Kampar yaitu warga belajar untuk kejar paket $B$ harus sudah memiliki Ijazah SD sedangkan pada kejar paket $C$ harus sudah memiliki Ijazah tingkat SMP." (transkip wawancara dengan Kepala SKB (Sanggar Kegiatan Belajar) Kabupaten Kampar).

Evaluasi mengenai warga belajar semua sub aspek sudah memenuhi standar objektifitas. Kemudian pada aspek pamong belajar dan tutor ada satu sub aspek yang belum memenuhi standar objektifitas karena masih ada tutor yang memiliki kualifikasi pendidikan tamatan SMA, jadi solusinya tutor yang memiliki kualifikasi pendidikan yang SMA ini di anjurkan untuk melanjutkan pendidikan kejenjang yang lebih tinggi yaitu D3 dan S1.

Evaluasi input pada aspek kurikulum juga masih ada sub aspek yang perlu diperbaiki yaitu pada kalender pendidikan yang mana penetapan jadwal belajar tidak sesuai dengan kalender pendidikan yang sudah diberikan oleh Dinas Pandidikan Kabupaten Kampar.

Sesuai dengan pendapat Siskandar (2003), kurikulum berbasis kompetensi adalah pengembangan kurikulum yang bertitik tolak dari kompetensi yang seharusnya dimiliki siswa setelah menyelesaikan pendidikan, yang meliputi pengetahuan, keterampilan, nilai dan pola berpikir serta bertindak sebagai refleksi dari pemahaman dan penghayatan yang telah dipelajari siswa.

Selanjutnya evaluasi pada aspek sarana dan prasarana juga masih ada yang belum memenuhi standar objektifitas yaitu sarana pendukung belajar terutama jumlah modul masih kurang 
sehingga proses belajar tidak efisien. Kemudian pada aspek pembiayaan itu masih bisa ditolerir dengan memungut biaya kepada warga dengan cara angsuran. Batas angsurannya sampai pada pengambilan ijazahnya. Dapat disimpulkan bahwa hasil evaluasi pada komponen input ini berada pada kategori baik, karena masih ada beberapa sub aspek yang belum memenuhi standar objektifitas.

Hasil analisis peneliti dari hasil wawancara dengan informan dan dari data yang diperoleh maka evaluasi pada komponen masukan (input) bahwa ada 5 aspek yang terdapat pada komponen input, dari 5 aspek ini hanya 1 aspek yang memenuhi standar objektifitas yaitu aspek warga belajar yang mana warga belajar tersebut harus sudah terdaftar di SKB tersebut, semua warga harus sudah memiliki ijazah SMP dan sudah membayar administrasinya. Peneliti berharap agar pada aspek warga belajar ini SKB Kabupaten Kampar dapat mempertahankan.

Aspek yang kedua yaitu pamong dan tutor, pada aspek ini ada 2 sub aspek yaitu pamong belajar memiliki latar belakang pendidikan minimal S1 dan ternyata pada sub aspek ini sudah memenuhi standar obejktif. Tetapi pada sub aspek yang kedua yaitu tutor memiliki latar belakang pendidikan minimal D3 dan ternyata pada sub aspek tutor ini belum memenuhi standar objektif yang mana tutor yang ada di SKB Kabupaten Kampar ini masih ada yang pendidikannya masih tamatan SMA. Jadi peneliti memberikan masukan atau saran agar para tutor yang pendidikannya belum memenuhi sayarat yang ditetapkan SKB tersebut dapat melanjutkan pendidikannya kejenjang yang lebih tinggi agar dapat meningkatkan hasil kerja mereka.

Aspek yang ketiga yaitu kurikulum. Pada aspek kurikulum ini terdapat 4 sub aspek, dari 4 sub aspek tersebut ada 1 sub aspek yang perlu ada perbaikan yaitu pada sub aspek kalender pendidikan. Kalender pendidikan ini seharusnya sudah ada di SKB (Sanggar Kegiatan Belajar) Kabupaten kampar sebelum masuknya tahun ajaran baru agar penetapan jadwal program sebagai pedoman pelaksanaan program SKB dapat disusun dengan tepat, dan pelaksanaan program dapat dilaksanakan dengan efisien dan konsisten.

Aspek yang keempat yaitu sarana dan prasarana, pada aspek ini terdapat 3 sub aspek dan ada 1 aspek yang perlu perbaikan yaitu sarana pendukung belajar atau disebut juga dengan modul yang jumlahnya masih kurang. Untuk itu diharapkan Pemerintah Kabupaten Kampar khususnya Dinas Pendidikan dan Kebudayaan Kabupaten Kampar dapat menanggulangi kekurangan jumlah modul ini agar pelaksanaan pembelajaran pada SKB (Sanggar Kegiatan Belajar) Kabupaten Kampar ini dapat terlaksana dengan baik.

Sedangkan pada aspek yang kelima yaitu aspek pembiayaan itu bisa ditolerir. Peneliti berharap untuk ke depannya masalah pembiayaan ini dapat lebih diperhatikan oleh Pemerintah Kabupaten Kampar, agar program SKB (Sanggar Kegiatan Belajar) dalam menanggulangi pendidikan anak putus sekolah lebih dapat ditingkatkan lagi sehingga jumlah anak yang putus sekolah di Kabupaten Kampar setiap tahunnya dapat di minimalisasi.

\section{- Evaluasi Proses}

Hasil dari evaluasi pada komponen proses dapat dilihat bahwa pada proses sosialisasi pelaksanaan program Sanggar Kegiatan Belajar (SKB) khususnya pada program kejar paket C seluruh sub aspek sudah dapat mencapai standar objektifitas.

Evaluasi proses pada aspek upaya dalam pelaksanaan Sanggar Kegiatan Belajar (SKB) khususnya pada program Kejar Paket $C$ terdapat dua sub aspek yang tidak memenuhi standar objektifitas yaitu pada sub aspek penggunaan media belajar yaitu komputerisasi dan sub aspek pemberian materi remedial kepada warga belajar yang belum mencapai ketuntasan pada nilai ulangan hariannya.

Sedangkan evaluasi pada aspek struktur organisasi program dan aspek kesiapan bahan ajar sudah memenuhi standar objektifitas. Selanjutnya evaluasi pada aspek kesiapan 
pamong belajar masih ada satu sub aspek yang belum memenuhi standar objektifitas yaitu sub aspek pamong belajar datang pada tepat waktu.

Evaluasi proses pada aspek hambatan yang ditemukan dalam melaksanakan program memiliki tiga sub aspek, hasil dari evaluasi di lapangan ketiga sub aspek masih ditemukan hambatannya.

Selanjutnya pada aspek koordinasi warga belajar, aspek pelaksanaan pembelajaran dan pada aspek pelaporan hasil pelaksanaan program itu semua sub aspeknya sudah memenuhi sandar objektifitas.

Jadi hasil dari evaluasi program Sanggar Kegiatan Belajar (SKB) pada komponen proses ini terdapat pada kategori kurang baik karena masih banyak sub aspek yang belum memenuhi standar objektifitas. Kemudian hambatan yang ditemui dalam pelaksanaan programnya semua sub aspeknya masih ditemukan hambatannya. Peneliti berharap pada evaluasi komponen proses ini harus lebih diperhatikan karena masih banyak sub aspek yang tidak memenuhi syarat objektif. Pada sub aspek penggunaan media belajar diharapkan kepada pamong dan tutor agar lebih menguasai teknologi dalam memberikan pembelajaran agar proses pembelajaran dapat dijalankan dengan efisien. Kemudian di dalam pemberian materi remedial para pamong dan tutor tersebut harus lebih meningkatkan pemberian materi remedial tersebut agar hasil yang diterima oleh para warga Paket $\mathrm{C}$ tersebut lebih kompeten.

Hasil analisis peneliti dari hasil wawancara dengan informa terhadap aspek struktur program SKB (Sanggar Kegiatan Belajar) Kabupaten Kampar itu tidak memenuhi syarat karena SKB Kabupaten Kampar sebelum melaksanakan programnya ini tidak membuat struktur programnya terlebih dahulu. Untuk kedepannya peneliti berharap sebelum melaksanakan programnya seharusnya terlebih dahulu dibuat struktur programnya, agar dalam pelaksanaan program tersebut dapat dilaksanakan sesuai dengan urutan dan waktu yang telah ditentukan sebelumnya dan dapat terlaksana dengan baik.
Kemudian pada aspek kesiapan pamong yaitu pada sub aspek pamong belajar masih datang terlambat maka peneliti berharap kedisiplinan pada pamong tersebut harus lebih ditingkatkan agar menjalankan tugas sebagai pamong belajar tersebut dapat dijalankan dengan penuh tanggungjawab.

Pada aspek hambatan yang ditemui dalam pelaksanaan program, ini harus lebih diperhatikan lagi karena semua sub aspek yang terdapat di aspek hambatan ini semuanya ditemukan hambatan. Hasil dari analisis peneliti mengenai hambatan yang ditemukan ini adalah karena kurangnya SKB (Sanggar Kegiatan Belajar) Kabupaten Kampar ini menerapkan kedisiplinan. Untuk itu kedepannya peneliti berharap agar SKB Kabupaten Kampar dalam melaksanakan programnyaitu lebih mengutamakan kedisiplinan, agar hambatan-hambatan yang ditemui dalam pelaksanaan program tersebut dapat diatasi.

\section{- Evaluasi Produk}

Evaluasi produk ini dapat dilihat dari hasil akhir pelaksanaan program khususnya program kejar paket $C$ dan tingkat keberhasilan dari warga belajar serta dampak dari kelulusan warga belajar tersebut.

Hasil akhir dari pelaksanaan program SKB (Sanggar Kegiatan Belajar) Kabupaten Kampar khususnya program kejar paket C dalam menanggulangi anak putus sekolah di Kabupaten Kampar, itu ditandai dengan adanya ujian akhir belajar. Waktu pelaksanaannya ditentukan oleh SKB (Sanggar Kegiatan Belajar) tersebut sesuai dengan hasil rapat Kepala SKB (Sanggar Kegiatan Belajar) dengan para pamong dan segenap pegawai di SKB (Sanggar Kegiatan Belajar) tersebut.

Tingkat keberhasilan warga belajar, itu dapat dilihat dari hasil raport para warga belajar. Dan hasil dari Ujian Nasional yang telah ditetapkan dari Jakarta langsung.

Kemudian dampak dari kelulusan warga belajar, hasil wawancara dengan salah seorang warga belajar yang sudah lulus mengatakan:

“.........saya sangat bersyukur dapat 
mengikuti program kejar paket $C$ di SKB ini, sebab dengan adanya saya memiliki ijazah yang setara dengan SMA sekarang ini saya dapat bekerja di Kantor Desa ini. Karena pertama kali saya mencoba untuk melamar pekerjaan sebagai KAUR (Kepala Urusan) di Kantor Desa ini salah satu syaratnya adalah harus memiliki ijazah SMA minimalnya." (Transkip wawancara dengan Abdissaleh, salah seorang warga belajar pada Sanggar Kegiatan Belajar (SKB) Kabupaten Kampar).

Dilihat dari hasil wawancara dengan warga belajar di SKB (Sanggar Kegiatan Belajar) Kabupaten Kampar yang sudah tamat, maka dapat dibuktikan bahwa program SKB (Sanggar Kegiatan Belajar) Kabupaten Kampar dapat menanggulangi pendidikan anak putus sekolah.

Dari hasil evaluasi ke empat komponen mulai dari komponen konteks, input, proses dan produk, maka dapat disimpulkan bahwa hasil evaluasi dari program Sanggar Kegiatan Belajar (SKB) Kabupaten Kampar dalam menanggulangi pendidikan anak putus sekolah khususnya pada program kejar paket $\mathrm{C}$ terdapat pada kategori baik. Karena dari hasil evaluasi hanya pada komponen proses saja yang hasilnya kurang baik, sedangkan pada komponen input hasilnya baik, pada komponen konteks dan produk hasilnya sangat baik, karena sudah memenuhi standar objektifitas. Peneliti berharap agar program SKB (Sanggar Kegiatan Belajar) Kabupaten Kampar ini dapat selalu menjalankan dan melaksanakan programnya dan lebih meningkatkan aspek-aspek yang telah peneliti evaluasi terutama pada aspek proses agar program SKB (Sanggar Kegiatan Belajar) Kabupaten Kampar ini dapat selalu menanggulangi pendidikan anak putus sekolah.

\section{SIMPULAN DAN SARAN}

Berdasarkan deskripsi data hasil penelitian dan pembahasan yang dikemukakan pada Bab IV, berikut ini disajikan kesimpulan-kesimpulan yang diambil, yaitu: a. Evaluasi Konteks

Tujuan program dari SKB Kabupaten Kampar dalam menanggulangi pendidikan anak putus sekolah berada pada katagori sangat baik karena aspek dan subaspek memenuhi standar objektif.

b. Evaluasi Input

Bahwa pada evaluasi input berada pada kategori baik yakni terdapat lima aspek yaitu aspek warga belajar, aspek pamong dan tutor, aspek kurikulum, aspek sarana dan prasarana dan aspek pembiayaan. Dari lima aspek ini hanya satu aspek yang sudah memenuhi standar objektif yaitu aspek warga belajar.

\section{c. Evaluasi Proses}

Bahwa terdapat 9 aspek yakni aspek sosialisasi pelaksanaan program SKB (Sanggar Kegiatan Belajar), Upaya dalam pelaksanaan program, Struktur Organisasi Program SKB, Kesiapan bahan ajar, Kesiapan pamong belajar, Hambatan yang ditemui dalam pelaksanaan program, pengkoordinasian warga belajar, pelaksanaan pembelajaran dan Pelaporan hasil program. Dan 28 subaspek. Dari 28 subaspek terdapat 2 subaspek yang tidak memenuhi standar objektif yaitu penggunan media pembelajaran dan pemberian materi remedial. Kemudian pada aspek hambatan yang ditemui dalam pelaksanaan program ke 3 subaspek memang ditemukan hambatannya.

\section{d. Evaluasi Produk}

Dari hasil evaluasi produk dari program Sanggar Kegiatan Belajar (SKB) Kabupaten Kampar berada pada kategori sangat baik karena aspek pada evaluasi produk tersebut sudah memenuhi standar objektif yakni aspek hasil akhir pelaksanaan program, tingkat keberhasilan dari warga belajar dan aspek dampak kelulusan.

Dari hasil penelitian evaluasi program SKB (Sanggar Kegiatan Belajar) Kabupaten Kampar dalam menanggulangi pendidikan anak putus sekolah maka peneliti dapat memberikan saran sebagai berikut: 
a. Pelaksanaan program SKB (Sanggar Kegiatan Belajar) Kabupaten Kampar akan lebih baik apabila dipersiapkan terlebih dahulu secara benar, baik dan lengkap dengan memperhatikan aspek-aspek konteks, input, proses dan produk sehingga pelaksanaan program SKB (Sanggar Kegiatan Belajar) Kabupaten Kampar akan terarah dan terukur.

b. Dinas Pendidikan dan Kebuadayaan Kabupaten Kampar sebaiknya lebih memperhatikan Sanggar Kegiatan Belajar (SKB) Kabupaten Kampar agar programnya dapat lebih ditingkatkan lagi sehingga jumlah anak putus sekolah di Kabupaten Kampar tersebut dapat di kurangi atau ditanggulangi.

\section{DAFTAR PUSTAKA}

Bagong Suyanto, 2013. Masalah Sosial Anak, Kencana, Surabaya

Budi Winarno, 2012. Teori dan Proses Kebijakan Publik, MedPress, Yogyakarta

Didi Prayitno, Partisipasi Masyarakat Dalam Implementasi Kebijakan Pemerintah ( Studi Kasus Pelaksanaan Program Wajib Belajar Sembilan Tahun Di Distrik Semangga, Kabupaten Merauke ), Program Pascasarjana Universitas Diponegoro, Program Studi : Magister Ilmu Administrasi Konsentrasi : Manajemen Publik

Djuju Sudjana, 2006. Evaluasi Program Pendidikan Luar Sekolah, PT Remaja Rosda Karya, Bandung

Farida Yusuf Tayibnapis, 2008. Evaluasi Program dan Instrumen Evaluasi, Rineka Cipta, Jakarta

Iskandar, 2013. Metodologi Penelitian Pendidikan dan Sosial, Referensi, Jakarta

Masrukhi, Tommi Yuniawan, Noorochmat Isdaryanto, Pelaksanaan Program Wajib Belajar 9 Tahun, Penyebaran Sekolah, Angka Partisipasi Kasar di Kabupaten Tegal, Univesitas Negeri Semarang
Mustofa Kamil, 2009. Pendidikan Nonformal, Alfabeta, Bandung

Moh Yamin, 2012. Sekolah yang Membebaskan, Madani, Malang

Profil dan Program Kerja UPTD SKB Bangkinang Kabupaten Kampar Tahun 2006

Rafiuddin Afkari bin Hj. Abdul Fattah, Peranan, Strategi dan Pola Pengembangan Pendidikan Mewujudkan Sumber Daya Manusia (SDM) di Inhil yang Berwawasan Maju dan Gemilang 2025, Fakulti Sains Sastera dan Warisan Universiti Tun Hussein Onn Malaysia

Riant Nugroho, 2008. Public Policy, Alex Medi a Komputindo, Jakarta

Rica Amanda, 2008. Analisis Efisiensi Teknis Bidang Pendidikan Dalam Implementasi Model Kota Layak Anak (Studi Kasus 14 Kabupaten/kota di Provinsi Jawa Tengah Tahun 2008),Program Sarjana Fakultas Ekonomi Universitas Diponegoro

Rocaety Eti, dkk, 2005. Sistem Informasi Manajemen Pendidikan, Bumi Aksara, Jakarta

Suharsimi Arikunto, 2008. Evaluasi Program Pendidikan, Bumi Aksara, Jakarta

Sukardi, 2014. Evaluasi Program Pendidikan dan Kepelatihan, PT Bumi Akasara, Jakarta.

Sugiyono, 2011. Metode Penelitian Pendidikan, Alfabeta, Bandung

Undang Undang Republik Indonesia Nomor 20

Tahun 2003 Tentang Sistem Pendidikan Nasional. 8 Juli 2003. Lembaran Negara Republik Indonesia Tahun 2003 Nomor 4301. Jakarta.

Wayne Parsons, 2005. Public Policy, Prenada Media, Jakarta 